\title{
RECENZJE カ RECENZJE カ RECENZJE
}

Sun Min, Papier, tusz i pedzel, czyli Traktat o chinskiej kaligrafii, przeł. zespó1 pod kierunkiem Wu Lan, Wydawnictwo Uniwersytetu Gdańskiego, Gdańsk 2017, ss. $238^{1}$

Aktywna wymiana kulturowa między Polską a Chinami zyskała szczególny wyraz w atrakcyjnej polskiej edycji książki sławnego chińskiego kaligrafa Sun Mina pt. Papier, tusz i pedzel, czyli traktat o chińskiej kaligrafii (Gdańsk 2017). Chińska wersja książki została wyróżniona Szanghajską Nagrodą Kaligraficzną, zaś autor otrzymał w roku 2006 tytuł Osobowości Roku w tejże dziedzinie. Polską edycję wydaną staraniem Wydawnictwa Uniwersytetu Gdańskiego przy współpracy z Centrum Studiów Azji Wschodniej Uniwersytetu Gdańskiego uczczono w Chinach w 2017 r. uroczysta promocja podczas sierpniowych Dni Książki w Szanghajskim Centrum Wystawienniczym. Trzeba dodać, że Wydawnictwo UG, przystępując do pracy, otrzymało upoważnienie Wydawnictwa Książek Klasycznych w Szanghaju wraz z informacją o nominacji książki do B\&R Book Program, powołanego do zagranicznej promocji dzieł chińskich.

Wieloletnią pracę nad przekładem chińskiego traktatu prowadził Zespół

1 Recenzja nawiązuje do tekstu omawiającego książkę Sun Mina, opublikowanego w 2017 r. w czasopiśmie „Napis”, Seria XXIII, s. $420-424$. wybitnych sinologów - absolwentów uczelni chińskich i polskich, obecnie pracujących w Polsce. Merytoryczną pieczę nad pracą Zespołu sprawowała prof. Wu Lan, dyrektor wykonawcza Instytutu Konfucjusza przy Uniwersytecie Gdańskim. Wybór wymienionego traktatu oznacza wprowadzenie i zbliżenie polskiego czytelnika do sztuki kaligrafii, przeżywającej obecnie światowy wzrost zainteresowań. Przekład wypracowany wspólną pracą translatorów wyróżnia się jasnością trudnego, objaśniającego wywodu i szlachetnym zredagowaniem formuł tak odległych kulturowo. Dzięki temu polski czytelnik zbliży się do pisma mistrzów kaligrafii i w poczuciu zrozumienia przekroczy mur pięciu tysiącleci historii tej sztuki. Chińska kaligrafia jako malowanie słowa jest artystycznym kunsztem wyrażającym ducha artysty, jego myśli i emocje towarzyszące stawianiu znaków.

Książkę otwiera Wstęp informujący adeptów kunsztu kaligrafii o niezbędnym przygotowaniu duchowym, intelektualnym, estetycznym i praktycznym, umożliwiającym podążanie ścieżką kaligrafii. W ocenie predyspozycji debiutanta uwzględniono zarówno znajomość dzieł mistrzów i traktatów teoretycznych, jak i wymaganą osobowość oraz talent. Wśród tych objaśnień umieszczono także pojęcia użyte w tytule książki, czyli papier, pędzel i tusz, które stanowią tzw. skarby gabinetu. Objaśnienie znaczeń i użycia skarbów gabinetu przy 
wyborze określonej techniki kaligrafii stanowi pasjonująca lekturę.

Cele książki mają charakter poznawczy, historyczny i prezentacyjny - objaśniający istotę, tajemnicę i ducha kaligrafii. Ważny jest też zamysł bezpośrednio edukacyjny, unaoczniający historyczny rozwój tejże sztuki. Funkcję tę realizują zamieszczone tablice piktogramów, znaków wróżebnych, inskrypcje kamienne, napisy na wachlarzach, jedwabnych tkaninach. Tablice służą także objaśnieniu stylów pisma i ich podziałowi na styl pieczęciowy, kancelaryjny, wzorcowy, bieżący, trawiasty, aż do szkicowego. W zamieszczonych wzornikach stylów oddających układ zapisów, niezbędnym, zawsze ozdobnym elementem jest czerwona osobista pieczęć kaligrafa.

Praca obejmuje pięć rozdziałów. Pierwszy z nich ma charakter historycznego przeglądu rozwoju pisma za czasów kolejnych dynastii i łączy wydarzenia polityczneorazi procesy społeczne z powstawaniem nowych nurtów kaligrafii, np. w epoce Ming. Rozdział drugi zawiera wykład klasycznych form kompozycyjnych. Część tę wyróżnia objaśniane klasycznych nazw materiałowych i łączenie ich z pojęciami materialnymi (np. zwoje, duplety - czyli zapisy równoległe, nadto wachlarze, albumy etc.). Rozdział trzeci służy ćwiczeniom praktycznym - od opisów postawy, prowadzenia ręki aż do bezpośredniego użycia pędzla, tuszu i papieru. Tu ważną rolę odgrywają rady i przestrogi oraz przykłady projektowania kompozycji. Zgodnie $z$ radą wyobraźnia podpowiada indywidualne widzenie swej drogi $\mathrm{i}$ jest to spojrzenie w lustro prawdy.
Rozdział czwarty poświęcono $W a$ lorom estetycznym sz̨tuki kaligrafii, która zmierza do opisania piękna i bogactwa świata. By je uchwycić, kaligraf przywołuje cechy kluczowe każdej rzeczy; unikając polityki, szuka inspiracji w naturze (,tylko prawe serce nakreśli doskonałą kreskę"). Piąty rozdział, dotyczący cech sztuki kaligrafii, zajmuje się wyborem mistrza, przyjęciem artystycznego stylu i wskazaniem zasad naśladownictwa wielkich dzieł. Młody mistrz odnajdzie droge respektowania tych wartości. Ostatni, szósty rozdział eksponuje Wybrane prayklady i przechodzi do omówienia sytuacji sztuki kaligrafii w komunikacji dnia bieżącego. W naturalny sposób sztuka kaligrafii zmierza do spotkania ze współczesnymi elektronicznymi środkami komunikacji, w których znaki kodu komputerowego praktycznie zastępuja tradycyjne pismo. Tempo komunikacji obniżyło szacunek do tradycyjnych wartości, a kaligrafia udziela dziś duchowego wsparcia dzięki zapisanym trwałym wartościom i ocaleniu uroku doskonałości form.

Dalsze rozważania koncentrują się na kryteriach oceny dzieła kaligraficznego. Wartościowaniu podlega zarówno wizualność, a więc spójność elementów, podział na wersy, usytuowanie pieczęci, kolorystyka, jak i treść dzieła oraz sfera intencji i emocji. Zdolność oceny zależy także od kultury, wiedzy i wrażliwości artystycznej odbiorcy. Wśród zamieszczonych tu cytowań sztuki poetyckiej przywołam słowa poety Kanga Youwei, który, patrząc na starożytne chińskie inskrypcje na kamiennych bębnach, napi- 
sał: „Sa jak ornamenty ze złotych nici zdobiące ziemię".

Tchnienie szlachetności omawianego tomu zostało też wydobyte kształtem i forma wydawniczą opracowana przez Wydawnictwo UG. Wartości te uwydatniły się podczas wieczoru promocyjnego książki. Spotkanie prowadziła prof. Wu Lan, niestrudzona w swej aktywności i promocji chińskiej kultury wysokiej. Uroczystość odbyła się w Instytucie Konfucjusza przy Uniwersytecie Gdańskim przy organizacyjnym i merytorycznym współudziale Wydawnictwa UG i Centrum Studiów Azji Wschodniej UG. Obok znakomitego wykładu prof. Wu Lan o sztuce kaligrafii, część merytoryczną wypełniły relacje o osiagnięciach i rozwoju badań nad kulturą chińską w gdańskiej Uczelni. Głos zabrał prof. Kamil Zeidler, znawca tej problematyki i redaktor Joanna Kamień, która jako dyrektor Wydawnictwa przedstawiła zbiór gdańskich edycji o tematyce chińskiej.

Część praktyczną spotkania przygotowała prof. Wu Lan wraz z zespołem wykształconych chińskich absolwentów „sztuki ułożonej ręki”. Każdy z obecnych mógł dzięki ich pomocy zapisać wybrane słowo znakami chińskiej kaligrafii. Poznawanie tej trudnej sztuki stawało się miarą szacunku dla niej.

Irena Kadulska 